\title{
Synthesis of a D-Ring Isomer of Galanthamine via a Radical-Based Smiles Rearrangement Reaction
}

\author{
Ping Lan, Colin J. Jackson, Martin G. Banwell,* and Anthony C. Willis \\ Research School of Chemistry, Institute of Advanced Studies, The Australian National University, Canberra, ACT 0200, Australia
}

Supporting Information

ABSTRACT: The 1,9-ethanoiminomethano-bridged tetrahydrodibenzo[ $[b, d]$-furan 2 , a non-natural isomer of the alkaloid (-)-galanthamine (1) varying in the manner in which the $\mathrm{D}$-ring is annulated to the $\mathrm{ABC}$-core, has been prepared in racemic form. The synthetic sequence starts with the cyclopropane 3 and involves intramolecular Heck alkenylation and radical-based Smiles rearrangement reactions as key steps. Unlike natural product $\mathbf{1}$, but as predicted by docking studies, compound $\mathbf{2}$ is not a potent inhibitor of acetylcholine esterase.

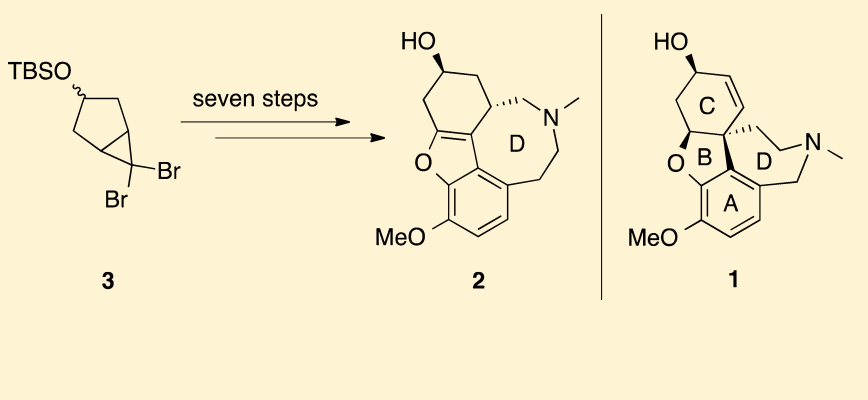

$\mathrm{T}$ he Amaryllidaceae alkaloid (-)-galanthamine $(\mathbf{1})^{1}$ is a potent, competitive, and reversible inhibitor of acetylcholine esterase $(\mathrm{AChE})^{2}$ as well as an allosterically potentiating ligand of the neuronal nicotinic receptor for acetylcholine. ${ }^{2 a}$ As a result of such properties and its capacity to penetrate the blood-brain barrier, ${ }^{1 \mathrm{a}, \mathrm{b}}$ the compound is now used clinically in the symptomatic treatment of mild to moderate forms of Alzheimer's disease. ${ }^{1,3}$ It has also been suggested that galanthamine and/or various of its congeners could be developed as agents for the treatment of facial nerve paralysis ${ }^{4}$ and schizophrenia ${ }^{5}$ as well as antidotes to poisoning by toxic organophosphorous compounds such as the nerve agent sarin. ${ }^{6}$

(-)-Galanthamine (1) has been obtained for commercial purposes by various means including through its extraction from a range of plants ${ }^{1 a, b, 7,8}$ such as the Caucasian snowdrop (Galanthus woronowii) and by synthesis. ${ }^{9,10}$ Nevertheless, establishing new and reliable supplies of the alkaloid remains an important objective, ${ }^{1}$ and as such, novel methods for the synthesis of compound 1 continue to be reported. ${ }^{1 \mathrm{c}, 11}$ In addition there is an ongoing interest in developing analogues of galanthamine possessing improved therapeutic properties. ${ }^{12}$ It is against this background that we have sought to identify means for rapidly assembling compound $\mathbf{1}$ and various analogues, especially ones that act as inhibitors of AChE. Accordingly, we now report a seven-step synthesis of the racemic modification of the galanthamine isomer 2 that differs from congener 1 by virtue of embodying a 1,9-ethanoiminomethano-bridged $\mathrm{ABC}$-ring core of the natural product. An unusual radical-based Smiles rearrangement reaction ${ }^{13}$ is involved in the late-stage formation of this eight-membered D-ring analogue of galanthamine.

The reaction sequence leading to compound 2 is shown in Scheme 1 and starts with the thermally induced electrocyclic ring opening of the previously reported ${ }^{14}$ ring-fused $\mathrm{gem}$ dibromocyclopropane 3 (5:1 mixture of diastereoisomers). The resulting mixture of vicinally dibrominated cyclohexenes in
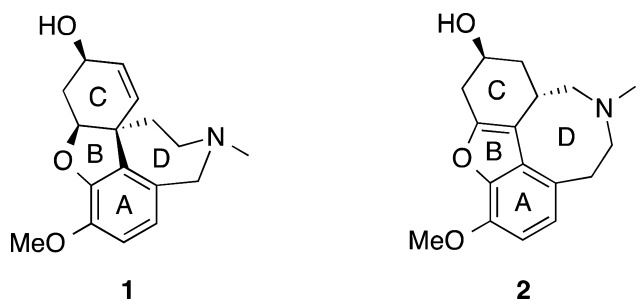

which diastereoiosmer $\mathbf{4}$ is presumed to predominate was immediately treated with isovanillin (5) in the presence of silver oxide, thereby generating a ca. 6:1 mixture of ether 6 and its epimer (94\% combined yield). The structure of compound 6 was confirmed by single-crystal X-ray analysis (see Experimental Section for details).

Using a protocol established by Willis and co-workers, ${ }^{15}$ the mixture of ether 6 and its epimer was engaged in an intramolecular Heck alkenylation reaction and so affording the corresponding mixture of tetrahydrodibenzofuran 7 and its epimer ( $76 \%$ combined yield). Reductive amination of the latter mixture using 2-(methylamino)ethanol in the presence of sodium triacetoxyborohydride ${ }^{16}$ and acetic acid then afforded aminoalcohol 8 together with small amounts of the corresponding trans-isomer. Subjection of this mixture of compound $\mathbf{8}$ and its isomer to an Appel reaction ${ }^{17}$ using carbon tetrabromide and triphenylphosphine then gave the rather unstable bromide $9(61 \%)$ as a single diastereoisomer. In the pivotal step of the reaction sequence, the success or otherwise of which was critically dependent on the purity of the substrate, halide 9 was treated with $\mathrm{Bu}_{3} \mathrm{SnH}$ and 2-[azo(1cyano-1-methylethyl)]-2-methylpropane nitrile (AIBN) in chlorobenzene at $140{ }^{\circ} \mathrm{C}$ and thereby forming a complex mixture of products including (based on the compounds finally

Received: June 5, 2014

Published: June 30, 2014 


\section{Scheme 1}

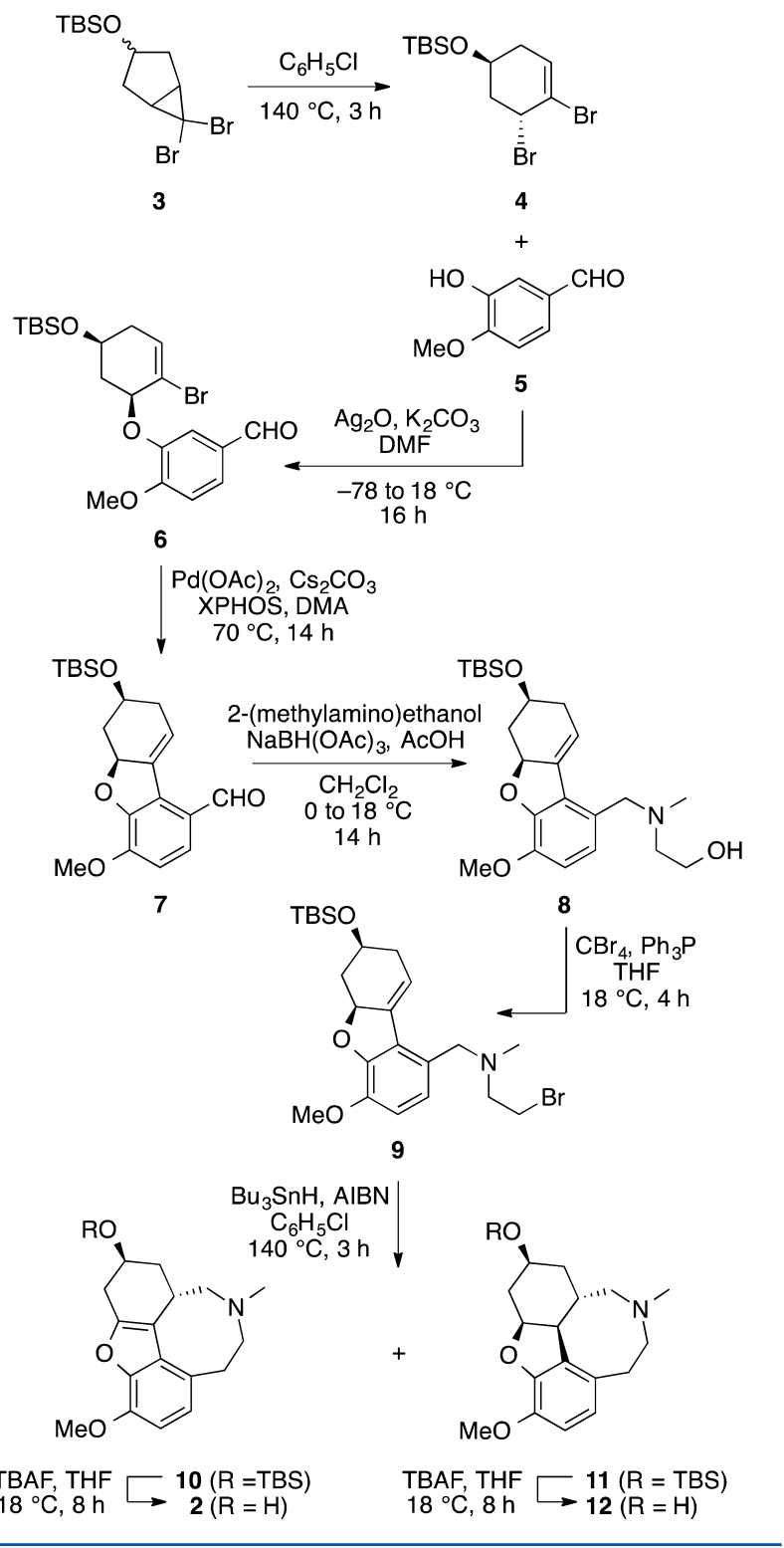

isolated) the tetracyclic systems $\mathbf{1 0}$ and $\mathbf{1 1}$. To facilitate the separation of the constituents, this mixture was treated with tetra- $n$-butylammonium fluoride (TBAF) and thereby converting any silyl ethers into the corresponding alcohols. Subjection of the resulting material to careful chromatographic purification provided compound 2 (12\%), while treatment of one of the other chromatographic fractions with picric acid resulted in the formation of the very small quantities of crystals of the salt derived from amine $\mathbf{1 2}$.

The spectral data acquired on compound $\mathbf{2}$ were in complete accord with the illustrated structure, but final confirmation of this was established by single-crystal X-ray analysis (see Experimental Section for details). Interestingly, certain of the higher-field signals observed in the ${ }^{13} \mathrm{C}$ NMR spectrum of tetracycle 2 recorded in $\mathrm{CDCl}_{3}$ at $25{ }^{\circ} \mathrm{C}$ showed considerable line-broadening, a feature that is attributed to slow interconversion of various of the conformations associated with the eight-membered D-ring. Significant sharpening of these signals was observed when the spectrum was recorded at $50{ }^{\circ} \mathrm{C}$. The structure of the picric acid salt derived from amine
12 also follows from single-crystal X-ray analysis (see Experimental Section for details), but because of the very small amounts of material obtained no other spectral data could be acquired on this material.

A reaction pathway that accounts for the conversion of substrate 9 into products $\mathbf{1 0}$ and $\mathbf{1 1}$ is shown in Scheme 2. Thus, the radical 13 formed by $\mathrm{Bu}_{3} \mathrm{SnH}$-mediated reduction of bromide 9 could engage in a spirocyclisation reaction to give isomer $\mathbf{1 4}$ that then fragments in what would be the second step of a radical-based Smiles rearrangement ${ }^{13}$ and thereby generating the nitrogen-stabilized primary radical $15 .^{18}$ This last species would then participate in an 8-endo-trig cyclization ${ }^{19}$ reaction to give the benzylic-type radical 16 that either aromatizes through loss of a hydrogen atom (to give benzofuran 10) or abstracts a hydrogen atom to afford the dihydrobenzofuran 11 .

In an effort to improve the efficiency of the conversion $9 \rightarrow$ 10 the former compound was treated with dilauroyl peroxide (DLP) in refluxing chlorobenzene (Scheme 3), conditions used by Zard et al. in their studies ${ }^{13 a}$ on radical-based Smiles rearrangement processes, but the only isolable product of reaction obtained under these conditions was the double-bond shifted (and aromatized) isomer 17 (63\%). In contrast, treatment of substrate 9 with DLP and then $\mathrm{Bu}_{3} \mathrm{SnH} / \mathrm{AIBN}$ in refluxing chlorobenzene afforded compound 18 (40\%) that presumably arises via successive double-bond migration and Smiles rearrangement reactions and wherein the radical arising from the second step of the latter process does not engage in a 7-exo-trig cyclization reaction because of the attendant disruption to the aromatic character of the benzofuran moiety. On treatment with TBAF, silyl ether $\mathbf{1 8}$ was readily converted into the corresponding alcohol 19 (82\%) for which superior spectral data could be obtained. The spectral data sets acquired on compounds 18 and 19 were in complete accord with the assigned structures. The most notable features within the ${ }^{1} \mathrm{H}$ and ${ }^{13} \mathrm{C}$ NMR spectra of alcohol 19 were the presence of signals (at $\delta_{\mathrm{H}} 2.36$ and $\delta_{\mathrm{C}} 45.3$, respectively) due to two equivalent methyl groups attached at nitrogen and thus indicating that a Smiles-type rearrangement reaction had occurred.

Given the isomeric relationship between compound 2 and (-)-galanthamine $[(-)-1]$ the former was evaluated for its capacity to act as an inhibitor of AChE using minor modifications ${ }^{20}$ to a simple and commonly employed assay developed for this purpose. ${ }^{21}$ The commercially available hydrobromide salt of the natural product was used as the source of the positive control (-)-1 and in this assay it displayed an $\mathrm{IC}_{50}$ of $<2 \mu \mathrm{M}$, a value consistent those reported elsewhere. ${ }^{12 \mathrm{a}}$ In contrast, the $\mathrm{IC}_{50}$ of isomer 2 was $>100 \mu \mathrm{M}$, thus indicating it is not a strong inhibitor of AChE. This outcome is consistent with molecular docking studies. Thus, the published crystal structure of $(-)$-galanthamine bound at the active site of Torpedo californica-derived AChE reveals (see Figure $1 \mathrm{~A}$ ) that the cyclohexene C-ring of the alkaloid, the mean plane of which is almost orthogonal to remaining (A, B, and $D)$ rings of the molecular framework, stacks against the indole ring of tryptophan 84. As such, the shape of (-)-galanthamine is highly complementary to the contours of the active site of AChE, occupying both the choline binding site and the acyl-binding pocket. ${ }^{22}$ In contrast, both enantiomers of compound 2 (see Figure $1 \mathrm{~B}$ and $\mathrm{C}$ ) are, by virtue of the differing mode of annulation of the $\mathrm{D}$-ring to the $\mathrm{ABC}$-core, significantly more planar than (-)-galanthamine with the result 


\section{Scheme 2}

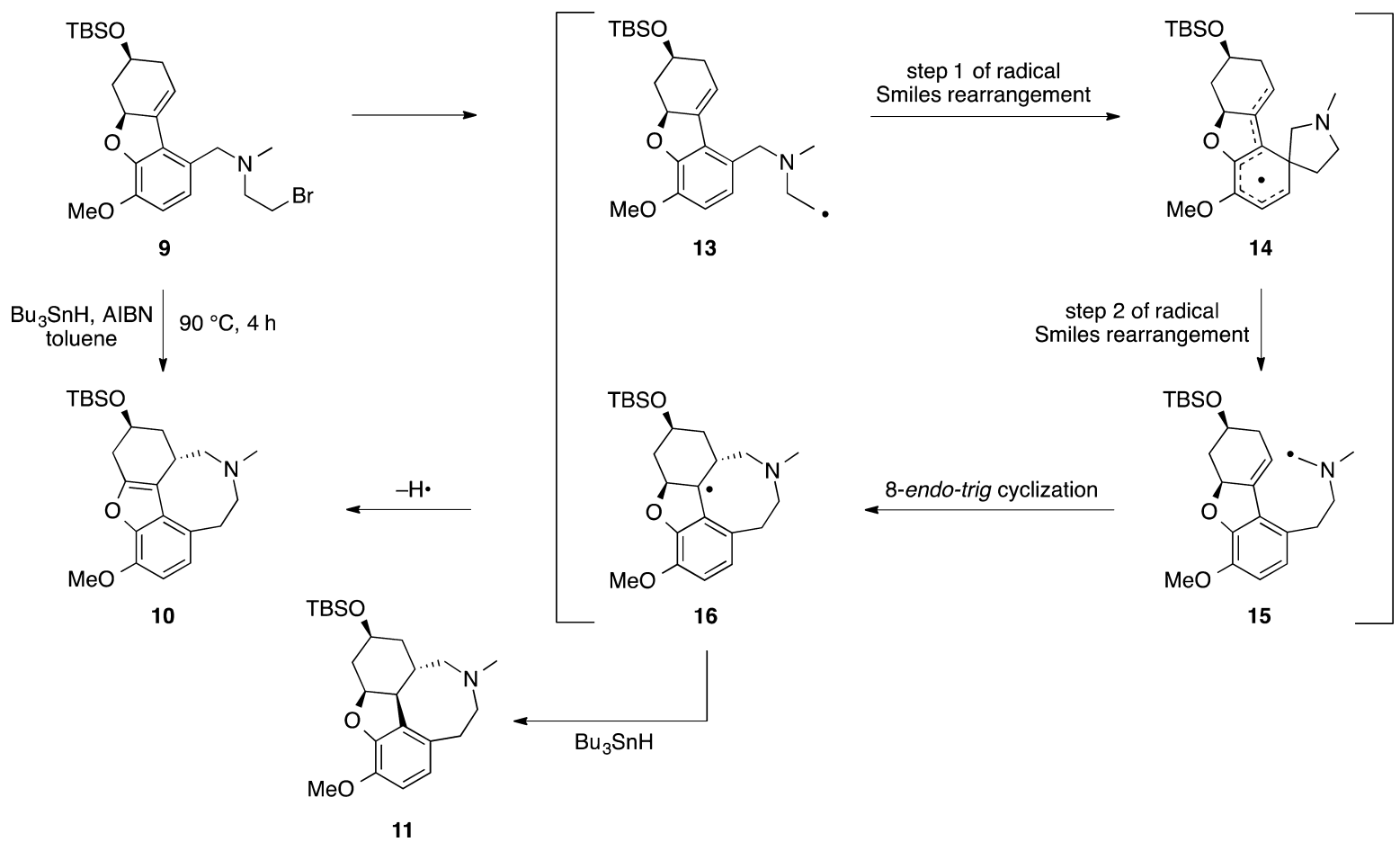

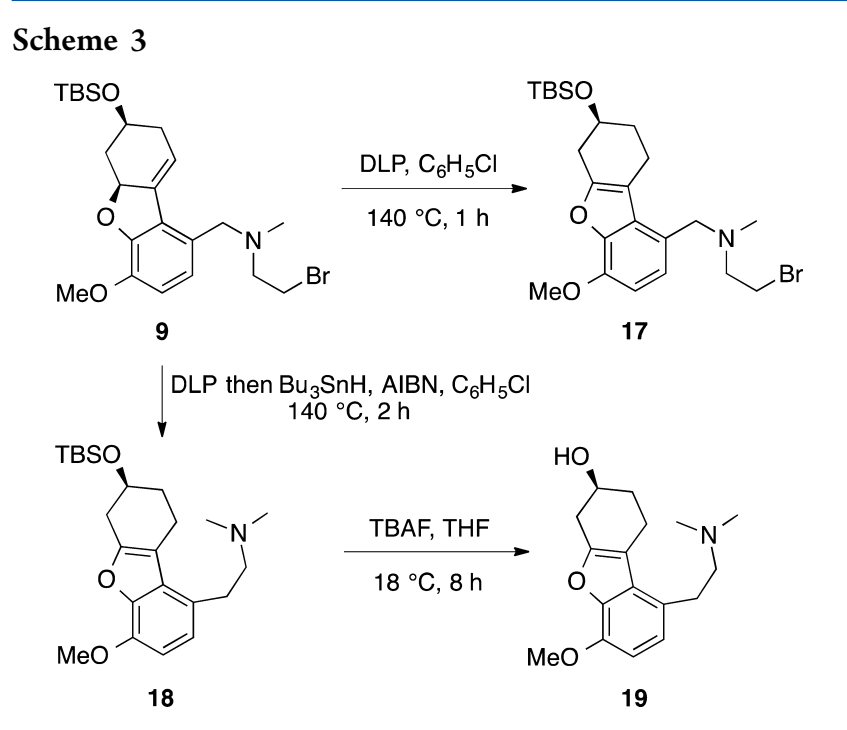

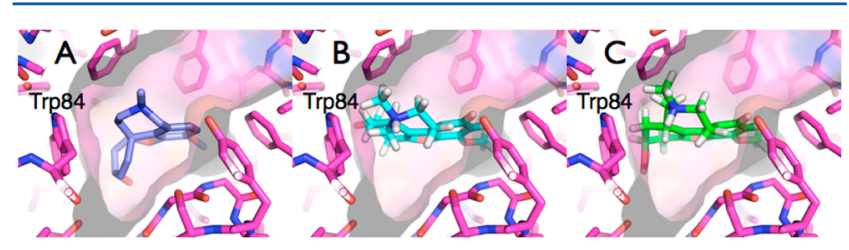

Figure 1. (A) (-)-Galanthamine bound in the active site of AChE (PDB: 1DX6) illustrating the complementary shapes of the inhibitor and the active site as well as the favorable interactions with the indole group of tryptophan 84 (Trp84). (B and C) Docking of the enantiomeric forms of compound 2 (S,S-enantiomer shown in panel B and $R, R$-enantiomer shown in panel $\mathrm{C}$ ) in the same active site that reveals the loss of interactions with Trp84 as well as the introduction of steric clashes that would restrict binding.

that stabilizing cyclohexene-indole interactions of the type defined above are now not possible. Furthermore, the less- folded/more-extended nature of framework of 2 results in steric clashes with other amino acid side chains within the active site.

The synthetic chemistry studies detailed above indicate that tertiary amines incorporating benzyl and $\beta$-bromoethyl moieties can participate in radical-based Smiles rearrangement reactions with the product radical then being capable of adding to a suitably located and nonaromatic $\pi$-system. This type of reactivity should be capable of exploitation in a range of settings. The biological studies described here suggest that galanthamine analogues/isomers wherein the mode of annulation of the $\mathrm{D}$-ring to the $\mathrm{ABC}$-core results in near planarization of whole framework (as seen in 2) are unlikely to be effective inhibitors of AChE.

\section{EXPERIMENTAL SECTION}

General Protocols. Unless otherwise specified, proton $\left({ }^{1} \mathrm{H}\right)$ and carbon $\left({ }^{13} \mathrm{C}\right)$ NMR spectra were recorded at room temperature in base-filtered $\mathrm{CDCl}_{3}$ on a spectrometer operating at $400 \mathrm{MHz}$ for proton and $100 \mathrm{MHz}$ for carbon nuclei. The signal due to residual $\mathrm{CHCl}_{3}$ appearing at $\delta_{\mathrm{H}} 7.26$ and the central resonance of the $\mathrm{CDCl}_{3}$ "triplet" appearing at $\delta_{\mathrm{C}} 77.0$ were used to reference ${ }^{1} \mathrm{H}$ and ${ }^{13} \mathrm{C}$ NMR spectra, respectively. ${ }^{1} \mathrm{H}$ NMR data are recorded as follows: chemical shift $(\delta)$ [multiplicity, coupling constant $(\mathrm{s}) J(\mathrm{~Hz})$, relative integral] where multiplicity is defined as $\mathrm{s}=\operatorname{singlet} ; \mathrm{d}=$ doublet; $\mathrm{t}=$ triplet; $\mathrm{q}=$ quartet; $\mathrm{m}=$ multiplet or combinations of the above. Samples were analyzed by infrared spectrometry $\left(\nu_{\max }\right)$ as thin films on $\mathrm{KBr}$ plates. Low-resolution ESI mass spectra were recorded on a single quadrupole liquid chromatograph-mass spectrometer, while high-resolution measurements were conducted on a time-of-flight instrument. Lowand high-resolution EI mass spectra were recorded on a magneticsector machine. Melting points are uncorrected. Analytical thin layer chromatography (TLC) was performed on aluminum-backed $0.2 \mathrm{~mm}$ thick silica gel $60 \mathrm{~F}_{254}$ plates. Eluted plates were visualized using a 254 nm UV lamp and/or by treatment with a suitable dip followed by heating. These dips included phosphomolybdic acid/ceric sulfate/ sulfuric acid (conc)/water $(37.5 \mathrm{~g} / 7.5 \mathrm{~g} / 37.5 \mathrm{~g} / 720 \mathrm{~mL})$ or potassium permanganate/potassium carbonate $/ 5 \%$ sodium hydroxide aqueous solution/water $(3 \mathrm{~g} / 20 \mathrm{~g} / 5 \mathrm{~mL} / 300 \mathrm{~mL})$. Flash chromatographic 
separations were carried out following protocols defined by Still et al. ${ }^{23}$ with silica gel $60(40-63 \mu \mathrm{m})$ as the stationary phase and using the AR- or HPLC-grade solvents indicated. Starting materials, reagents, drying agents, and other inorganic salts were generally commercially available and were used as supplied. Tetrahydrofuran (THF), methanol, and dichloromethane were dried using a solvent purification system that is based upon a technology originally described by Grubbs et al. ${ }^{24}$ Where necessary, reactions were performed under a nitrogen atmosphere.

Compound 6. A magnetically stirred solution of dibromocyclopropane $3^{14}(3.50 \mathrm{~g}, 9.45 \mathrm{mmol})$ in chlorobenzene $(30 \mathrm{~mL})$ was heated at reflux for $3 \mathrm{~h}$ while being maintained under a nitrogen atmosphere. The cooled reaction mixture was concentrated under reduced pressure and the residue, presumed to contain dibromide 4 and its epimer, was dissolved in dry DMF $(40 \mathrm{~mL})$. The ensuing and magnetically stirred solution was maintained at $-78{ }^{\circ} \mathrm{C}$ under a nitrogen atmosphere while being treated with anhydrous $\mathrm{K}_{2} \mathrm{CO}_{3}(1.57$ g, $11.34 \mathrm{mmol})$, isovanillin (5) (1.73 g, $11.34 \mathrm{mmol})$, and $\mathrm{Ag}_{2} \mathrm{O}(2.63$ $\mathrm{g}, 11.34 \mathrm{mmol}$ ), and the flask containing the ensuing mixture was immediately wrapped in aluminum foil to exclude light. The resulting mixture was warmed to $18{ }^{\circ} \mathrm{C}$ over $16 \mathrm{~h}$, then poured into brine $(100$ $\mathrm{mL})$, and extracted by ethyl acetate $(3 \times 100 \mathrm{~mL})$. The combined organic layers were then dried $\left(\mathrm{Na}_{2} \mathrm{SO}_{4}\right)$, filtered, and concentrated under reduced pressure. The residue thus obtained was subjected to flash chromatography (silica, 1:10 v/v ethyl acetate/hexane elution) to afford, after concentration of the relevant fractions $\left(R_{f}=0.6\right.$ in $1: 5 \mathrm{v} / \mathrm{v}$ ethyl acetate/hexane), a ca. 6:1 mixture of compound 6 and its epimer (3.90 g, 94\%) as an amorphous, white powder; ${ }^{1} \mathrm{H}$ NMR $(400 \mathrm{MHz}$, $\left.\mathrm{CDCl}_{3}\right) \delta$ (major diastereoisomer) $9.84(\mathrm{~s}, 1 \mathrm{H}), 7.55(\mathrm{~d}, J=1.8 \mathrm{~Hz}$, $1 \mathrm{H}), 7.50(\mathrm{dd}, J=8.2$ and $1.8 \mathrm{~Hz}, 1 \mathrm{H}), 7.00(\mathrm{~d}, J=8.2 \mathrm{~Hz}, 1 \mathrm{H}), 6.19$ $(\mathrm{m}, 1 \mathrm{H}), 5.00(\mathrm{~m}, 1 \mathrm{H}), 4.01-3.96($ complex m, $1 \mathrm{H}), 3.94(\mathrm{~s}, 3 \mathrm{H})$, 2.46-2.40 (complex m, 1H), 2.37-2.27 (complex m, 1H), 2.23-2.14 (complex m, 1H), 2.07-1.99 (complex m, 1H), $0.86(\mathrm{~s}, 9 \mathrm{H}), 0.06(1)$ $(\mathrm{s}, 3 \mathrm{H}), 0.05(6)(\mathrm{s}, 3 \mathrm{H}) ;{ }^{13} \mathrm{C}$ NMR $\left(100 \mathrm{MHz}, \mathrm{CDCl}_{3}\right) \delta$ (major diastereoisomer) $190.7,155.9,147.9,131.1,129.9,127.2,122.2,114.7$, 111.4, 77.6, 65.8, 56.2, 39.8, 37.2, 25.7, 18.0, -4.6(5), -4.7(3); IR $(\mathrm{KBr}) \nu_{\max } 2953,2930,2856,1690,1597,1583,1508,1462,1434$, 1390, 1271, 1112, 1020, $994 \mathrm{~cm}^{-1}$; MS (ESI, +ve) $\mathrm{m} / z 463$ and 465 $\left(\mathrm{M}+\mathrm{Na}^{+}, 93\right.$ and 100\%); HRMS (ESI, +ve) $(\mathrm{M}+\mathrm{H})^{+}$calcd for $\mathrm{C}_{20} \mathrm{H}_{30}{ }^{79} \mathrm{BrO}_{4} \mathrm{Si} 441.1097$, found 441.1054.

A sample of compound 6 suitable for single-crystal X-ray analysis was crystallized from hexane/ethyl acetate, $\mathrm{mp} 86-89^{\circ} \mathrm{C}$.

Compound 7. A magnetically stirred mixture of compound 6 and its epimer $(4.70 \mathrm{~g}, 10.6 \mathrm{mmol})$ in $N, N$-dimethylacetamide (DMA) (36 $\mathrm{mL}$ ) was purged with argon for $0.33 \mathrm{~h}$ before being treated with $\mathrm{Pd}(\mathrm{OAc})_{2}(190 \mathrm{mg}, 0.85 \mathrm{mmol})$, XPhos $(810 \mathrm{mg}, 1.70 \mathrm{mmol})$, and $\mathrm{Cs}_{2} \mathrm{CO}_{3}(5.20 \mathrm{~g}, 15.9 \mathrm{mmol})$. The ensuing mixture was heated at 70 ${ }^{\circ} \mathrm{C}$ for $14 \mathrm{~h}$ while being maintained under a nitrogen atmosphere, and then the cooled solution was poured into brine $(150 \mathrm{~mL})$ and extracted with ethyl acetate $(3 \times 150 \mathrm{~mL})$. The combined organic phases were dried $\left(\mathrm{Na}_{2} \mathrm{SO}_{4}\right)$, filtered, and concentrated under reduced pressure, and the residue thus obtained was subjected to flash chromatography (silica, 1:9 v/v ethyl acetate/hexane elution) to afford, after concentration of the relevant fractions $\left(R_{f}=0.6\right.$ in $1: 5 \mathrm{v} / \mathrm{v}$ ethyl acetate/hexane), a ca. 6:1 mixture of compound 7 and its epimer $(2.90 \mathrm{~g}, 76 \%)$ as a pale-yellow oil; ${ }^{1} \mathrm{H}$ NMR $\left(400 \mathrm{MHz}, \mathrm{CDCl}_{3}\right) \delta$ (major diastereoisomer) $9.99(\mathrm{~s}, 1 \mathrm{H}), 7.40(\mathrm{~d}, J=8.4 \mathrm{~Hz}, 1 \mathrm{H}), 6.86$ $(\mathrm{d}, J=8.4 \mathrm{~Hz}, 1 \mathrm{H}), 6.69(\mathrm{~m}, 1 \mathrm{H}), 5.14(\mathrm{~m}, 1 \mathrm{H}), 4.14(\mathrm{~m}, 1 \mathrm{H}), 3.96$ (s, 3H), $2.70(\mathrm{~m}, 1 \mathrm{H}), 2.60(\mathrm{~m}, 1 \mathrm{H}), 2.29(\mathrm{~m}, 1 \mathrm{H}), 1.92(\mathrm{~m}, 1 \mathrm{H}), 0.91$ (s, 9H), 0.10(1) (s, 3H), 0.09(8) (s, 3H); ${ }^{13} \mathrm{C}$ NMR (100 MHz, $\mathrm{CDCl}_{3}$ ) $\delta$ (major diastereoisomer) 190.4, 151.7, 149.7, 135.9, 128.4, $126.7,125.6,123.4,110.8,83.6,66.4,56.1,37.7,36.5,25.8,18.1$, $-4.6(8),-4.7(2)$; IR (KBr) $\nu_{\max } 2955,2931,2856,1689,1603,1571$, $1508,1463,1426,1400,1283,1253,1197,1170,1103,987,883,838$, $776 \mathrm{~cm}^{-1}$; MS (ESI, +ve): $m / z 383\left(\mathrm{M}+\mathrm{Na}^{+}, 100 \%\right)$; HRMS (ESI, + ve) $(\mathrm{M}+\mathrm{H})^{+}$calcd for $\mathrm{C}_{20} \mathrm{H}_{29} \mathrm{O}_{4} \mathrm{Si} 361.1835$, found 361.1832.

Compound 8. A magnetically stirred mixture of compound 7 and its epimer $(1.20 \mathrm{~g}, 3.33 \mathrm{mmol})$ in $\mathrm{CH}_{2} \mathrm{Cl}_{2}(40 \mathrm{~mL})$ maintained at $0{ }^{\circ} \mathrm{C}$ under a nitrogen atmosphere was treated with 2-(methylamino)ethanol (400 $\mu \mathrm{L}, 5.00 \mathrm{mmol}), \mathrm{NaBH}(\mathrm{OAc})_{3}(1.77 \mathrm{~g}, 8.33 \mathrm{mmol})$, and acetic acid $(570 \mu \mathrm{L}, 9.99 \mathrm{mmol})$. The ensuing solution was warmed to $18{ }^{\circ} \mathrm{C}$ over $14 \mathrm{~h}$, then basified using $\mathrm{K}_{2} \mathrm{CO}_{3}(20 \mathrm{~mL}$ of a saturated aqueous solution), and extracted with $\mathrm{CH}_{2} \mathrm{Cl}_{2}(3 \times 40 \mathrm{~mL})$. The combined organic phases were dried $\left(\mathrm{Na}_{2} \mathrm{SO}_{4}\right)$, filtered, and concentrated under reduced pressure, and the residue thus obtained was subjected to flash chromatography (silica, 1:50 v/v methanol/ dichloromethane elution). Concentration of the relevant fractions $\left(R_{f}\right.$ $=0.3$ in ethyl acetate), a ca. $6: 1$ mixture of compound 8 and its epimer $(1.20 \mathrm{~g}, 86 \%)$ as a clear, colorless oil; ${ }^{1} \mathrm{H} \mathrm{NMR}\left(400 \mathrm{MHz}, \mathrm{CDCl}_{3}\right) \delta$ (major diastereoisomer) $6.74(\mathrm{~d}, J=8.2 \mathrm{~Hz}, 1 \mathrm{H}), 6.68(\mathrm{~d}, J=8.2 \mathrm{~Hz}$, $1 \mathrm{H}), 5.90(\mathrm{~m}, 1 \mathrm{H}), 5.04(\mathrm{~m}, 1 \mathrm{H}), 4.13(\mathrm{~m}, 1 \mathrm{H}), 3.86(\mathrm{~s}, 3 \mathrm{H}), 3.64(\mathrm{~m}$, $1 \mathrm{H}), 3.59-3.49$ (complex m, 3H), 2.65-2.53 (complex m, 5H), 2.292.26 (complex m, 1H), $2.24(\mathrm{~s}, 3 \mathrm{H}), 1.90(\mathrm{~m}, 1 \mathrm{H}), 0.90(\mathrm{~s}, 9 \mathrm{H})$, $0.09(0)(\mathrm{s}, 3 \mathrm{H}), 0.08(5)(\mathrm{s}, 3 \mathrm{H}) ;{ }^{13} \mathrm{C} \mathrm{NMR}\left(100 \mathrm{MHz}, \mathrm{CDCl}_{3}\right) \delta$ (major diastereoisomer) 151.4, 144.3, 138.3, 126.5, 125.2, 122.9, $117.9,111.4,83.0,66.6,59.9,58.4,57.7,55.9,41.3,37.7,36.3,25.8$, $18.1,-4.7\left(2 \times \mathrm{CH}_{3}\right) ; \mathrm{IR}(\mathrm{KBr}) \nu_{\max } 3451,2953,2931,2856,1617$, 1586, 1511, 1462, 1416, 1276, 1255, 1100, 1005, 985, 883, 837, 776 $\mathrm{cm}^{-1}$; MS (EI, $\left.70 \mathrm{eV}\right) \mathrm{m} / z 419\left(\mathrm{M}^{+\bullet}, 40 \%\right), 388(60), 346(70), 345$ (99), 214 (40), 187 (100); HRMS (EI, $70 \mathrm{eV)} \mathrm{M}^{+}$calcd for $\mathrm{C}_{23} \mathrm{H}_{37} \mathrm{NO}_{4} \mathrm{Si} 419.2492$, found 419.2493 .

Compound 9. A magnetically stirred mixture of compound 8 and its epimer $(1.00 \mathrm{~g}, 2.38 \mathrm{mmol})$ in dry THF $(20 \mathrm{~mL})$ maintained at 18 ${ }^{\circ} \mathrm{C}$ under a nitrogen atmosphere was treated with $\mathrm{CBr}_{4}(950 \mathrm{mg}, 2.86$ mmol) and $\mathrm{Ph}_{3} \mathrm{P}(750 \mathrm{mg}, 2.86 \mathrm{mmol})$. The ensuing solution was stirred at $18{ }^{\circ} \mathrm{C}$ for $14 \mathrm{~h}$ and then concentrated under reduced pressure. The residue thus obtained was subjected to flash chromatography (silica, $1: 15 \mathrm{v} / \mathrm{v}$ ethyl acetate/hexane elution) to afford, after concentration of the relevant fractions $\left(R_{f}=0.9\right.$ in $1: 5 \mathrm{v} / \mathrm{v}$ ethyl acetate/hexane), compound $9(700 \mathrm{mg}, 61 \%)$ as a clear, colorless oil; ${ }^{1} \mathrm{H}$ NMR $\left(400 \mathrm{MHz}, \mathrm{CDCl}_{3}\right) \delta 6.80(\mathrm{~d}, J=8.3 \mathrm{~Hz}, 1 \mathrm{H}), 6.70(\mathrm{~d}, J$ $=8.3 \mathrm{~Hz}, 1 \mathrm{H}), 6.02(\mathrm{~m}, 1 \mathrm{H}), 5.04(\mathrm{~m}, 1 \mathrm{H}), 4.13(\mathrm{~m}, 1 \mathrm{H}), 3.87(\mathrm{~s}$, $3 \mathrm{H}), 3.62(\mathrm{~d}, J=12.9 \mathrm{~Hz}, 1 \mathrm{H}), 3.49(\mathrm{~d}, J=12.9 \mathrm{~Hz}, 1 \mathrm{H}), 3.39(\mathrm{t}, J=$ $6.8 \mathrm{~Hz}, 2 \mathrm{H}$ ), 2.85-2.80 (complex m, $2 \mathrm{H}$ ), 2.64-2.54 (complex m, $2 \mathrm{H}), 2.29(\mathrm{~m}, 1 \mathrm{H}), 2.26(\mathrm{~s}, 3 \mathrm{H}), 1.94(\mathrm{~m}, 1 \mathrm{H}), 0.91(\mathrm{~s}, 9 \mathrm{H}), 0.10(1)$ $(\mathrm{s}, 3 \mathrm{H}), 0.09(7)(\mathrm{s}, 3 \mathrm{H}) ;{ }^{13} \mathrm{C} \mathrm{NMR}\left(100 \mathrm{MHz}, \mathrm{CDCl}_{3}\right) \delta 151.1,144.2$, 137.9, 126.4, 125.6, 122.9, 119.0, 111.4, 83.2, 66.7, 59.4, 58.8, 55.9, 41.8, 37.7, 36.4, 29.7, 25.8, 18.2, $-4.7\left(2 \times \mathrm{CH}_{3}\right)$; IR $(\mathrm{KBr}) \nu_{\max } 2953$, 2930, 2855, 1617, 1586, 1511, 1462, 1416, 1277, 1254, 1099, 1004, $985 \mathrm{~cm}^{-1}$; MS (EI, $\left.70 \mathrm{eV}\right) \mathrm{m} / z 481$ and $483\left(\mathrm{M}^{+\bullet}\right.$, both $\left.10 \%\right), 346$ (90), 289 (35), 244 (60), 214 (90), 187 (100); HRMS (EI, $70 \mathrm{eV)}$ $\mathrm{M}^{+\bullet}$ calcd for $\mathrm{C}_{23} \mathrm{H}_{36}{ }^{79} \mathrm{Br} \mathrm{NO} \mathrm{NO}_{3} \mathrm{Si} 481.1648$, found 481.1648 .

Compound 2. Step i: A magnetically stirred mixture of compound $9(300 \mathrm{mg}, 0.62 \mathrm{mmol})$ in chlorobenzene $(50 \mathrm{~mL})$ maintained under a nitrogen atmosphere at $140{ }^{\circ} \mathrm{C}$ was treated with AIBN $(61 \mathrm{mg}, 0.37$ $\mathrm{mmol}$ ) in four equal-sized aliquots over $3 \mathrm{~h}$ and simultaneously (dropwise via syringe pump) with $\mathrm{Bu}_{3} \mathrm{SnH}(250 \mu \mathrm{L}, 0.93 \mathrm{mmol})$ in chlorobenzene $(10 \mathrm{~mL})$ over $3 \mathrm{~h}$. After the additions were complete, the ensuing mixture was stirred at $140{ }^{\circ} \mathrm{C}$ for a further $1 \mathrm{~h}$ before being cooled and concentrated under reduced pressure. The residue thus obtained was subjected to flash chromatography (silica, ethyl acetate elution) to afford, after concentration of the relevant fractions $\left(R_{f}=\right.$ $0.2)$, a mixture of some five products $(120 \mathrm{mg}$ ) including compounds 10 and 11. This mixture was immediately subjected to the step ii of the reaction sequence.

Step ii: A magnetically stirred solution of the material obtained from step $\mathrm{i}$ in THF $(10 \mathrm{~mL})$ maintained under a nitrogen atmosphere was treated with TBAF $(1.0 \mathrm{~mL}$ of a $1 \mathrm{M}$ solution in THF solution, 1.0 $\mathrm{mmol}$ ). The ensuing mixture was stirred at $18{ }^{\circ} \mathrm{C}$ for $8 \mathrm{~h}$ and then concentrated under reduced pressure. The residue thus obtained was subjected to conventional column (not flash) chromatography (silica, $1: 9 \mathrm{v} / \mathrm{v}$ ammonia-saturated methanol/dichloromethane elution) to afford two fractions, $\mathrm{A}$ and $\mathrm{B}$.

Concentration of fraction $\mathrm{A}\left[R_{f}=0.5(5)\right]$ afforded a light-yellow oil $(50 \mathrm{mg})$ that was dissolved in methanol (ca. $5 \mathrm{~mL}$ ), and the resulting solution was treated with picric acid $(50 \mathrm{mg})$ and allowed to stand in an open vessel at room temperature for 14 days. After this time a small crystal of compound $\mathbf{1 2}$ (suitable for a single-crystal X-ray analysis) was formed. CAUTION: picric acid and the derived amine salts can be explosive. 
Concentration of fraction B $\left[R_{f}=0.5(0)\right]$ gave compound $2(22 \mathrm{mg}$, $12 \%$ from 9) as a white, microcrystalline solid, mp $135-136{ }^{\circ} \mathrm{C} ;{ }^{1} \mathrm{H}$ $\operatorname{NMR}\left(400 \mathrm{MHz}, \mathrm{CDCl}_{3}\right) \delta 6.80(\mathrm{~d}, J=8.0 \mathrm{~Hz}, 1 \mathrm{H}), 6.61(\mathrm{~d}, J=8.0$ $\mathrm{Hz}, 1 \mathrm{H}), 4.34(\mathrm{~m}, 1 \mathrm{H}), 3.96(\mathrm{~s}, 3 \mathrm{H}), 3.51(\mathrm{~m}, 1 \mathrm{H}), 3.24(\mathrm{~m}, 1 \mathrm{H}), 3.12$ (dd, $J=16.4$ and $4.8 \mathrm{~Hz}, 1 \mathrm{H}), 3.02-2.70$ (complex m, 6H), $2.38(\mathrm{~s}$, $3 \mathrm{H}), 2.10$ (broad s, $1 \mathrm{H}), 2.04(\mathrm{~m}, 1 \mathrm{H}), 1.72(\mathrm{~m}, 1 \mathrm{H}) ;{ }^{13} \mathrm{C}$ NMR $(100$ $\left.\mathrm{MHz}, \mathrm{CDCl}_{3}, 50{ }^{\circ} \mathrm{C}\right) \delta 150.2,144.0,143.8,129.2,125.8,122.7,115.9$, $105.8,65.0,62.7,57.4,56.2,46.1,37.4,32.9,30.7,28.3$; IR (KBr) $\nu_{\max }$ $3350,2917,1627,1580,1511,1460,1384,1274,1209,1054,1010$, 850, $798 \mathrm{~cm}^{-1}$; MS (EI, $\left.70 \mathrm{eV}\right) \mathrm{m} / z 287\left(\mathrm{M}^{+}, 80 \%\right), 231$ (100), 200 (30); HRMS (EI, $70 \mathrm{eV}$ ) $\mathrm{M}^{+\bullet}$ calcd for $\mathrm{C}_{17} \mathrm{H}_{21} \mathrm{NO}_{3}$ 287.1521, found 287.1526.

Compound 17. A magnetically stirred mixture of compound 9 $(190 \mathrm{mg}, 0.39 \mathrm{mmol})$ in chlorobenzene $(24 \mathrm{~mL})$ maintained at $140{ }^{\circ} \mathrm{C}$ was treated with DLP $(64 \mathrm{mg}, 0.16 \mathrm{mmol})$ in two equal aliquots over 1 h. After the addition was complete, the cooled reaction mixture was concentrated under reduced pressure, and the residue thus obtained was subjected to flash chromatography (silica, 1:15 v/v ethyl acetate/ hexane elution). Concentration of the relevant fractions $\left(R_{f}=0.9\right.$ in $1: 5 \mathrm{v} / \mathrm{v}$ ethyl acetate/hexane) afforded compound 17 (120 mg, 63\%) as a clear, colorless oil; ${ }^{1} \mathrm{H}$ NMR $\left(400 \mathrm{MHz}, \mathrm{CDCl}_{3}\right) \delta 6.99(\mathrm{~d}, J=8.1$ $\mathrm{Hz}, 1 \mathrm{H}), 6.64(\mathrm{~d}, J=8.1 \mathrm{~Hz}, 1 \mathrm{H}), 4.23(\mathrm{~m}, 1 \mathrm{H}), 3.97(\mathrm{~s}, 3 \mathrm{H}), 3.70$ (m, 2H), $3.36(\mathrm{t}, J=7.4 \mathrm{~Hz}, 2 \mathrm{H}), 3.05-3.00$ (complex m, 2H), 2.892.80 (complex m, 3H), 2.73 (complex m, 1H), $2.26(\mathrm{~s}, 3 \mathrm{H}), 1.96-1.80$ (complex m, 2H), $0.90(\mathrm{~s}, 9 \mathrm{H}), 0.10(7)(\mathrm{s}, 3 \mathrm{H}), 0.09(5)(\mathrm{s}, 3 \mathrm{H}) ;{ }^{13} \mathrm{C}$ NMR $\left(100 \mathrm{MHz}, \mathrm{CDCl}_{3}\right) \delta 151.9,144.6,144.0,129.0,124.4,112.9$, 104.7 (two signals overlapping), 67.7, 59.7, 58.5, 55.9, 41.7, 33.6, 32.0, 29.8, 25.8, 19.6, 18.2, -4.7 $\left(2 \times \mathrm{CH}_{3}\right)$; IR $(\mathrm{KBr}) \nu_{\max } 2929,2854$, $1685,1623,1582,1512,1461,1413,1292,1251,1085,1008,834,777$ $\mathrm{cm}^{-1}$; MS (EI, $\left.70 \mathrm{eV}\right) \mathrm{m} / z 481$ and $483\left(\mathrm{M}^{+\bullet}\right.$, both $\left.10 \%\right), 346(40)$, 345 (83), 344 (100), 288 (33), 287 (50), 213 (40); HRMS (EI, 70 eV) $\mathrm{M}^{+\bullet}$ calcd for $\mathrm{C}_{23} \mathrm{H}_{36}{ }^{79} \mathrm{BrNO}_{3} \mathrm{Si} 481.1648$, found 481.1650 .

Compound 18. A magnetically stirred mixture of compound 9 (90 $\mathrm{mg}, 0.19 \mathrm{mmol})$ in chlorobenzene $(12 \mathrm{~mL})$ maintained at $140{ }^{\circ} \mathrm{C}$ was treated with DLP $(32 \mathrm{mg}, 0.08 \mathrm{mmol})$ in two equal aliquots over $1 \mathrm{~h}$. A solution of AIBN (13 mg, $0.08 \mathrm{mmol})$ and $\mathrm{Bu}_{3} \mathrm{SnH}(61 \mu \mathrm{L}, 0.23$ $\mathrm{mmol})$ in chlorobenzene $(12 \mathrm{~mL})$ was then added, in one portion, to the reaction mixture that was then stirred at $140{ }^{\circ} \mathrm{C}$ for a further $2 \mathrm{~h}$ before being cooled and concentrated under reduced pressure. The residue thus obtained was subjected to flash chromatography (silica, $1: 9 \mathrm{v} / \mathrm{v}$ ammonia-saturated methanol/dichloromethane elution) to afford, after concentration of the relevant fractions $\left(R_{f}=0.1\right.$ in ethyl acetate), compound 18 (30 mg, 40\%) as a clear, colorless oil; ${ }^{1} \mathrm{H}$ NMR $\left(400 \mathrm{MHz}, \mathrm{CDCl}_{3}\right) \delta 6.89(\mathrm{~d}, J=8.0 \mathrm{~Hz}, 1 \mathrm{H}), 6.65(\mathrm{~d}, J=8.0 \mathrm{~Hz}$, $1 \mathrm{H}), 4.24(\mathrm{~m}, 1 \mathrm{H}), 3.96(\mathrm{~s}, 3 \mathrm{H}), 3.05-2.94$ (complex m, 4H), 2.852.70 (complex m, 2H), 2.61-2.57 (complex m, 2H), $2.38(\mathrm{~s}, 6 \mathrm{H})$, 2.00-1.84 (complex m, 2H), $0.89(\mathrm{~s}, 9 \mathrm{H}), 0.10(3)(\mathrm{s}, 3 \mathrm{H}), 0.09(1)(\mathrm{s}$, $3 \mathrm{H}) ;{ }^{13} \mathrm{C}$ NMR $\left(100 \mathrm{MHz}, \mathrm{CDCl}_{3}\right) \delta 151.8,143.9,143.7,128.2$, 124.6, 123.2, 112.2, 105.4, 67.4, 62.1, 56.0, 45.3, 33.6, 31.8, 30.5, 25.8, $19.5,18.2,-4.7\left(2 \times \mathrm{CH}_{3}\right)$; IR $(\mathrm{KBr}) \nu_{\max } 2929,2853,1625,1512$, $1463,1293,1258,1082,1014,834 \mathrm{~cm}^{-1}$; MS (EI, $\left.70 \mathrm{eV}\right) \mathrm{m} / z 403$ $\left(\mathrm{M}^{+}, 5 \%\right), 58(100)$; HRMS (EI, $\left.70 \mathrm{eV}\right) \mathrm{M}^{+\bullet}$ calcd for $\mathrm{C}_{23} \mathrm{H}_{37} \mathrm{NO}_{3} \mathrm{Si}$ 403.2543, found 403.2542.

Compound 19. A magnetically stirred mixture of compound 18 $(30 \mathrm{mg}, 0.08 \mathrm{mmol})$ in THF $(5 \mathrm{~mL})$ was treated with TBAF $(1.0 \mathrm{~mL}$ of a $1 \mathrm{M}$ in THF solution, $1.0 \mathrm{mmol}$ ). The resulting solution was stirred at $18{ }^{\circ} \mathrm{C}$ for $8 \mathrm{~h}$ and then concentrated under reduced pressure. The residue thus obtained was subjected to flash chromatography (silica, $1: 5 \mathrm{v} / \mathrm{v}$ ammonia-saturated methanol/dichloromethane elution) to afford, after concentration of the relevant fractions $\left(R_{f}=0.7\right)$, compound 19 (18 mg, 82\%) as a clear, colorless oil; ${ }^{1} \mathrm{H}$ NMR (400 $\left.\mathrm{MHz}, \mathrm{CDCl}_{3}\right) \delta 6.88(\mathrm{~d}, J=8.1 \mathrm{~Hz}, 1 \mathrm{H}), 6.65(\mathrm{~d}, J=8.1 \mathrm{~Hz}, 1 \mathrm{H})$, $4.29(\mathrm{~m}, 1 \mathrm{H}), 3.96(\mathrm{~s}, 3 \mathrm{H}), 3.12(\mathrm{dd}, J=16.7$ and $5.1 \mathrm{~Hz}, 1 \mathrm{H}), 3.03-$ 2.95 (complex m, 3H), 2.90-2.86 (complex m, 1H), 2.78 (dd, $J=16.7$ and $5.1 \mathrm{~Hz}, 1 \mathrm{H}), 2.59-2.55($ complex $\mathrm{m}, 2 \mathrm{H}), 2.36(\mathrm{~s}, 6 \mathrm{H}), 2.06-1.93$ (complex m, 2H) (signal due to $\mathrm{OH}$ group proton not observed); ${ }^{13} \mathrm{C}$ NMR $\left(100 \mathrm{MHz}, \mathrm{CDCl}_{3}\right) \delta 151.1,143.9,143.7,128.0,124.8,123.3$, 112.1, 105.6, 66.6, 62.0, 56.0, 45.3, 33.0, 31.1, 30.4, 19.2; IR (KBr) $\nu_{\max }$ 3358, 2934, 2849, 1625, 1511,1462, 1445, 1291, 1206, 1098, 1053 $\mathrm{cm}^{-1}$; MS (EI, $\left.70 \mathrm{eV}\right) \mathrm{m} / z 289\left(\mathrm{M}^{+\bullet}, 7 \%\right), 58$ (100); HRMS (EI, 70 eV) $\mathrm{M}^{+\bullet}$ calcd for $\mathrm{C}_{17} \mathrm{H}_{23} \mathrm{NO}_{3} 289.1678$, found 289.1678.

Crystallographic Studies. Crystallographic Data. Compound 2. $\mathrm{C}_{17} \mathrm{H}_{21} \mathrm{NO}_{3}, M=287.36, T=200 \mathrm{~K}$, orthorhombic, space group $P 2_{1} 2_{1} 2_{1}, Z=4, a=6.2260(3), b=8.3026(3), c=28.0590(12) \AA ; \quad V=$ $1450.43(11) \AA^{3}, D_{x}=1.316 \mathrm{~g} \mathrm{~cm}^{-3}, 1529$ unique data $\left(2 \theta_{\max }=50.2^{\circ}\right)$, $R=0.037$ [for 1178 reflections with $I>2.0 \sigma(I)$ ]; $R w=0.082$ (all data), $S=0.95$.

Compound 6. $\mathrm{C}_{20} \mathrm{H}_{29} \mathrm{BrO}_{4} \mathrm{Si}, M=441.44, T=200 \mathrm{~K}$, monoclinic, space group $P 2_{1} / c, Z=4, a=12.0338(2), b=7.9720(1), c=$ 23.2133(4) $\AA ; \beta=97.5273(10)^{\circ} ; V=2207.74(6) \AA^{3}, D_{x}=1.328 \mathrm{~g}$ $\mathrm{cm}^{-3}, 5031$ unique data $\left(2 \theta_{\max }=55^{\circ}\right), R=0.034$ [for 3991 reflections with $I>2.0 \sigma(I)] ; R w=0.087$ (all data), $S=0.98$.

Picrate Salt of Compound 12. $\mathrm{C}_{17} \mathrm{H}_{24} \mathrm{NO}_{3}{ }^{+} \mathrm{C}_{6} \mathrm{H}_{2} \mathrm{~N}_{3} \mathrm{O}_{7}^{-}, M=$ $518.48, T=200 \mathrm{~K}$, monoclinic, space group $P 2_{1} / c, Z=4, a=$ 10.9504(2), $b=9.5641(2), c=21.5400(4) \AA ; \beta=97.2592(9)^{\circ} ; V=$ 2237.82(7) $\AA^{3}, D_{x}=1.539 \mathrm{~g} \mathrm{~cm}^{-3}, 5135$ unique data $\left(2 \theta_{\max }=55^{\circ}\right), R$ $=0.046$ [for 3650 reflections with $I>2.0 \sigma(I)] ; R w=0.120$ (all data), $S$ $=0.96$.

Structure Determinations. Images were measured on a CCD diffractometer (Mo K $\alpha$, graphite monochromator, $\lambda=0.71073 \AA$ ), and data were extracted using the DENZO package. ${ }^{25}$ Structure solution was by direct methods (SIR92) ${ }^{26}$ The structures of compounds 2, $\mathbf{6}$, and the picrate salt of compound $\mathbf{1 2}$ were refined using the CRYSTALS program package. ${ }^{27}$ Atomic coordinates, bond lengths and angles, and displacement parameters have been deposited at the Cambridge Crystallographic Data Centre (CCDC nos. 1004605, 1004606, and 1004607 for compounds 2 and 6 and the picrate salt of compound 12, respectively). These data can be obtained free of charge via www.ccdc.cam.ac.uk/data request/cif.

AchE Inhibitory Testing. The inhibitory effects of compound 2 toward Electrophorus electricus (electric eel)-derived AChE in $300 \mathrm{mM}$ $\mathrm{NaCl}$ maintained at $\mathrm{pH} 7.5$ were measured (at $25{ }^{\circ} \mathrm{C}$ and varying concentrations up to $100 \mu \mathrm{M}$ ) using $1 \mathrm{mM}$-nitrophenyl acetate substrate (in $2 \% \mathrm{v} / \mathrm{v}$ methanol, $20 \mathrm{mM}$ HEPES, and $300 \mathrm{mM} \mathrm{NaCl}$ maintained at $\mathrm{pH} 7.5,100 \mu \mathrm{L}$ final volume). Hydrolysis of $p$ nitrophenyl acetate was continuously monitored by observing any increase, over $10 \mathrm{~min}$, in absorbance at $405 \mathrm{~nm}$ (due to formation of the $p$-nitrophenolate anion) on a microplate spectrophotometer. Measurements were carried out in triplicate.

Molecular Docking Studies. The X-ray structures of each enantiomer of compound 2, obtained as described above, were submitted to the PRODRG server (http://davapcl.bioch.dundee.ac. uk/cgi-bin/prodrg), ${ }^{28}$ which generated optimized three-dimensional coordinates. No significant binding of either of these enantiomers was observed in the active site of Torpedo californica ACHE (1DX6) using Autodock $4.2^{29}$ with default settings. To better understand how the structural differences between (-)-galanthamine and the enantiomeric forms of its isomer 2 contribute to the loss of binding and inhibition, the structures of both enantiomers (of 2 ) were manually superimposed onto the bound structure of $(-)$-galanthamine in the active site of AChE using the program COOT v 0.7.30

\section{ASSOCIATED CONTENT}

\section{Supporting Information}

Crystallographic data (CIFs); anisotropic displacement ellipsoid plots derived from the single-crystal analyses of compounds 2, 6, and the picrate salt of compound 12; full spectral data for all new compounds except 10, 11, and 12. This material is available free of charge via the Internet at http:// pubs.acs.org.

\section{AUTHOR INFORMATION}

\section{Corresponding Author}

*E-mail: Martin.Banwell@anu.edu.au.

\section{Notes}

The authors declare no competing financial interest. 


\section{ACKNOWLEDGMENTS}

We thank the Australian Research Council and the Institute of Advanced Studies for financial support. P.L. is the grateful recipient of a CSC Ph.D. scholarship provided by the Government of the People's Republic of China. A/Professor Mal McLeod is thanked for providing a sample of the hydrobromide salt of (-)-galanthamine. We gratefully acknowledge Mr. Nicholas Fraser's assistance in undertaking the biological assays reported herein.

\section{REFERENCES}

(1) For reviews dealing with the isolation and development of (-)-galanthamine as a drug, see: (a) Heinrich, M.; Teoh, H. L. J. Ethnopharmacol. 2004, 92, 147. (b) Heinrich, M. The Alkaloids; Cordell, G. A., Ed.; Elsevier Inc.: Amsterdam, 2010; Vol. 68, Chapter 4, p 157. For a review detailing the synthesis and pharmacology of (-)-galanthamine, see: (c) Marco-Contelles, J.; do Carmo Carreiras, M.; Rodríguez, C.; Villarroya, M.; García, A. G. Chem. Rev. 2006, 106, 116.

(2) (a) Nordberg, A.; Svensson, A.-L. Drug Saf. 1998, 19, 465. (b) Lilienfeld, S. CNS Drug Rev. 2002, 8, 159.

(3) Sramek, J. J.; Frackiewicz, E. J.; Cutler, N. R. Expert Opin. Invest. Drugs 2000, 9, 2393.

(4) Młodzikowska-Albrecht, J.; Żarowski, M.; Steinborn, B.; Winczewska-Wiktor, A.; Gurda, B.; Wigowska-Sowińska, J. Rocz. Akad. Med. Bialymstoku 2005, 50 (Supplement 1), 64.

(5) Sacco, K. A.; Creeden, C.; Reutenauer, E. L.; George, T. P. Schizophrenia Res. 2008, 103, 326.

(6) Albuquerque, E. X.; Pereira, E. F. R.; Aracava, Y.; Fawcett, W. P.; Oliveira, M.; Randall, W. R.; Hamilton, T. A.; Kan, R. K.; Romano, J. A., Jr.; Adler, M. Proc. Natl. Acad. Sci. U.S.A. 2006, 103, 13220.

(7) (a) Torras-Claveria, L.; Berkov, S.; Codina, C.; Viladomat, F.; Bastida, J. Ind. Crops Prod. 2013, 43, 237. (b) Lubbe, A.; Gude, H.; Verpoorte, R.; Choi, Y. H. Phytochemistry 2013, 88, 43.

(8) Stanilova, M. I.; Molle, E. D.; Yanev, S. G. The Alkaloids; Cordell, G. A., Ed.; Elsevier Inc.: Amsterdam, 2010; Vol. 68, Chapter 5, p 167.

(9) Küenburg, B.; Czollner, L.; Fröhlich, J.; Jordis, U. Org. Process Res. Dev. 1999, 3, 425.

(10) Trinadhachari, G. N.; Kamat, A. G.; Prabahar, K. J.; Handa, V. K.; Srinu, K. N. V.; Babu, K. R.; Sanasi, P. D. Org. Process Res. Dev. 2013, 17, 406

(11) For syntheses and synthetic approaches reported after those cited in ref 1c, see: (a) Hu, X.-D.; Tu, Y. Q.; Zhang, E.; Gao, S.; Wang, S.; Wang, A.; Fan, C.-A.; Wang, M. Org. Lett. 2006, 8, 1823. (b) Satcharoen, V.; McLean, N. J.; Kemp, S. C.; Camp, N. P.; Brown, R. C. D. Org. Lett. 2007, 9, 1867. (c) Ishikawa, T.; Kudo, K.; Kuroyabu, K.; Uchida, S.; Kudoh, T.; Saito, S. J. Org. Chem. 2008, 73, 7498. (d) Reddy, J. M.; Kumar, K. V.; Raju, V.; Bhaskar, B. V.; Himabindu, V.; Bhattacharya, A.; Sundaram, V.; Banerjee, R.; Reddy, G. M.; Bandichhor, R. Synth. Commun. 2008, 38, 2138. (e) Magnus, P.; Sane, N.; Fauber, B. P.; Pynch, V. J. Am. Chem. Soc. 2009, 131, 16045. (f) Herke, K.; Hazai, L.; Hudák, M. S.; Ábrahám, J.; Sánta, Z.; Háda, V.; Szántay, C., Jr.; Szántay, C. C. ARKIVOC 2009, xi, 235. (g) Chandrasekhar, S.; Basu, D.; Sailu, M.; Kotamraju, S. Tetrahedron Lett. 2009, 50, 4882. (h) Kato, T.; Tanimoto, H.; Yamada, H.; Chida, N. Heterocycles 2010, 82, 563. (i) Banwell, M. G.; Ma, X.; Karunaratne, O. P.; Willis, A. C. Aust. J. Chem. 2010, 63, 1437. (j) Chang, J. H.; Kang, H.-U.; Jung, I.-H.; Cho, C.-G. Org. Lett. 2010, 12, 2016. (k) Chen, P.; Bao, X.; Zhang, L.-F.; Ding, M.; Han, X.-J.; Li, J.; Zhang, G.-B.; Tu, Y.-Q.; Fan, C.-A. Angew. Chem., Int. Ed. 2011, 50, 8161. (1) Chen, J.-Q.; Xie, J.-H.; Bao, D.-H.; Liu, S.; Zhou, Q.-L. Org. Lett. 2012, 14, 2714. (m) Zang, Y.; Ojima, I. J. Org. Chem. 2013, 78, 4013. (n) Choi, J.; Kim, H.; Park, S.; Tae, J. Synlett 2013, 24, 379. (o) Trinadhachari, G. N.; Kamat, A. G.; Babu, K. R.; Sanasi, P. D.; Prabahar, K. J. Tetrahedron: Asymmetry 2014, 25, 117.

(12) See, for example: (a) Herlem, D.; Martin, M.-T.; Thal, C.; Guillou, C. Bioorg. Med. Chem. Lett. 2003, 13, 2389. (b) Knesl, P.;
Yousefi, B. H.; Mereiter, K.; Jordis, U. Tetrahedron Lett. 2006, 47, 5701. (c) Berkov, S.; Codina, C.; Viladomat, F.; Bastida, J. Bioorg. Med. Chem. Lett. 2008, 18, 2263. (d) Jia, P.; Sheng, R.; Zhang, J.; Fang, L.; He, Q.; Yang, B.; Hu, Y. Eur. J. Med. Chem. 2009, 44, 772. (e) Bartolucci, C.; Haller, L. A.; Jordis, U.; Fels, G.; Lamba, D. J. Med. Chem. 2010, 53, 745. (f) de la Torre, P.; Saavedra, L. A.; Caballero, J.; Quiroga, J.; Alzate-Morales, J. H.; Cabrera, M. G.; Trilleras, J. Molecules 2012, 17, 12072. (g) Keglevich, P.; Kovács, P.; Hazai, L.; Sánta, Z.; Dubrovay, Z.; Háda, V.; Szántay, C., Jr.; Kalaus, G.; Szántay, C. Heterocycles 2012, 84, 1171. (h) Iannello, C.; Pigni, N. B.; Antognoni, F.; Poli, F.; Maxia, A.; de Andrade, J. P.; Bastida, J. Fitoterapia 2014, 92, 163. Certain derivatives of the alkaloid lycorine also act as potent inhibitors of AChE: (i) McNulty, J.; Nair, J. J.; Little, J. R. L.; Brennan, J. D.; Bastida, J. Bioorg. Med. Chem. Lett. 2010, 20, 5290.

(13) (a) Bacqué, E.; El Qacemi, M.; Zard, S. Z. Org. Lett. 2005, 7, 3817. (b) Pudlo, M.; Allart-Simon, I.; Tinant, B.; Gérard, S.; Sapi, J. Chem. Commun. 2012, 48, 2442 and references therein.

(14) Petit, L.; Banwell, M. G.; Willis, A. C. Org. Lett. 2011, 13, 5800.

(15) (a) Yagoubi, M.; Cruz, A. C. F.; Nichols, P. L.; Elliott, R. L.; Willis, M. C. Angew. Chem., Int. Ed. 2010, 49, 7958. For related approaches to the $\mathrm{ABC}$-ring substructure of galanthamine, see: (b) Pilger, C.; Westermann, B.; Flörke, U.; Fels, G. Synlett 2000, 1163. (c) Parsons, P. J.; Charles, M. D.; Harvey, D. M.; Sumoreeah, L. R.; Shell, A.; Spoors, G.; Gill, A. L.; Smith, S. Tetrahedron Lett. 2001, 42, 2209.

(16) Abdel-Magid, A. F.; Mehrman, S. J. Org. Process Res. Dev. 2006, $10,971$.

(17) van Kalkeren, H. A.; van Delft, F. L.; Rutjes, F. P. J. T. Pure Appl. Chem. 2013, 85, 817.

(18) See: Zipse, H. Top. Curr. Chem. 2006, 263, 163 and references therein.

(19) For examples of 8-endo-trig cyclization reactions involving carbon-centered radicals, see: (a) Molander, G. A.; George, K. M.; Monovich, L. G. J. Org. Chem. 2003, 68, 9533. (b) Ram, R. N.; Tittal, R. K.; Upreti, S. Tetrahedron Lett. 2007, 48, 7994. (c) Majumdar, K. C.; Mondal, S.; Ghosh, D. Tetrahedron Lett. 2010, 51, 348. (d) Saadi, J.; Brüdgam, I.; Reissig, H.-U. Beilstein J. Org. Chem. 2010, 6, 1229.

(20) Pfeffer, J. M.; Weadge, J. T.; Clarke, A. J. J. Biol. Chem. 2013, $288,2605$.

(21) Ellman, G. L.; Courtney, K. D.; Andres, V., Jr.; Featherstone, R. M. Biochem. Pharmacol. 1961, 7, 88.

(22) Greenblatt, H. M.; Kryger, G.; Lewis, T.; Silman, I.; Sussman, J. L. FEBS Lett. 1999, 463, 321.

(23) Still, W. C.; Kahn, M.; Mitra, A. J. Org. Chem. 1978, 43, 2923.

(24) Pangborn, A. B.; Giardello, M. A.; Grubbs, R. H.; Rosen, R. K.; Timmers, F. J. Organometallics 1996, 15, 1518.

(25) DENZO-SMN. Otwinowski, Z.; Minor, W. Processing of X-ray diffraction data collected in oscillation mode. In Methods in Enzymology, Vol. 276: Macromolecular Crystallography, Part A; Carter, C. W., Jr., Sweet, R. M., Eds.; Academic Press: New York, 1997; pp $307-326$.

(26) SIR92 Altomare, A.; Cascarano, G.; Giacovazzo, C.; Guagliardi, A.; Burla, M. C.; Polidori, G.; Camalli, M. J. Appl. Crystallogr. 1994, 27, 435 .

(27) Betteridge, P. W.; Carruthers, J. R.; Cooper, R. I.; Prout, K.; Watkin, D. J. J. Appl. Crystallogr. 2003, 36, 1487.

(28) Schüttelkopf, A. W.; van Aalten, D. M. F. Acta Crystallogr., Sect. D: Biol. Crystallogr. 2004, 60, 1355.

(29) Morris, G. M.; Huey, R.; Lindstrom, W.; Sanner, M. F.; Belew, R. K.; Goodsell, G. S.; Olson, A. J. J. Comput. Chem. 2009, 30, 2785.

(30) Emsley, P.; Lohkamp, B.; Scott, W. G.; Cowtan, K. Acta Crystallogr., Sect. D: Biol. Crystallogr. 2010, 66, 486. 